\title{
Facts of cripness to the Brazilian: dialogues with Avatar, the film
}

Fatos da aleijadice à brasileira: diálogos com Avatar, o filme

Anahi Guedes de Mello e Marco Antonio Gavério

\section{(2) OpenEdition \\ 12 Journals}

Edição electrónica

URL: http://journals.openedition.org/aa/3481

DOI: $10.4000 /$ aa.3481

ISSN: 2357-738X

Editora

Programa de Pós-Graduação em Antropologia Social (UnB)

\section{Edição impressa}

Data de publição: 1 junho 2019

Paginação: 43-65

ISSN: 0102-4302

\section{Refêrencia eletrónica}

Anahi Guedes de Mello e Marco Antonio Gavério, «Facts of cripness to the Brazilian: dialogues with Avatar, the film», Anuário Antropológico [Online], v.44 n. 1 | 2019, posto online no dia 06 julho 2019, consultado o 28 abril 2021. URL: http://journals.openedition.org/aa/3481 ; DOI: https://doi.org/ 10.4000/aa.3481

\section{(c) (i) (9)}

Anuário Antropológico is licensed under a Creative Commons Atribuição-Uso Não-Comercial-Proibição de realização de Obras Derivadas 4.0 International. 


\title{
Facts of cripness to the Brazilian: dialogues with Avatar, the film
}

\author{
Anahi Guedes de Mello \\ Universidade Federal de Santa Catarina - Brasil \\ Marco Antonio Gavério \\ Universidade Federal de São Carlos - Brasil
}

\section{Introduction}

Queer theory influenced disability studies, contributing towards the emergence of crip theory, proposed by Robert McRuer (2006), which relates cultural signs of queerness and disability. While the main axiom of queer theory postulates that contemporary society is governed by hetero-cis-normativity, crip theory builds itself upon the postulate of compulsory able-bodiedness of the social structure less sensitive to body diversity. The translation of the term crip, short for cripple, for the category of "aleijado" in Portuguese, is a way of approximating its definition in English. The meaning of the term crip initially was directed against all that does not fit within bodily/functional standards. It reveals the abject zone reserved for persons with disabilities. Similar to the term "queer", crip terminology has an openly aggressive, derogatory and subversive connotation. In order to mark a crip commitment towards developing an analytics of the normalization of the body, inspired by the work of deconstructionist authors like Michel Foucault (1990), Jacques Derrida (1998), Judith Butler (1990, 1993, 2004), among others, developing critiques around systems of oppression marked by patriarchy, by compulsory heterosexuality $^{1}$ (Rich, 1980) and the compulsory able-bodiedness (McRuer, 2002):

I argue that the system of compulsory able-bodiedness that produces disability is thoroughly interwoven with the system of compulsory heterosexuality that produces queerness; that - in fact - compulsory heterosexuality is contingent on compulsory able-bodiedness and vice versa. [...] The idea of imbricated systems is of course not new - Rich's own analysis repeatedly stresses the imbrication of compulsory heterosexuality and patriarchy. I would argue, however, as others have, the feminist and queer theories (and cultural theories generally) are not yet accustomed to figuring ability/disability into the equation, and thus this theory of compulsory able-bodiedness is offered as a preliminary contribution to that much-needed conversation (McRuer, 2002: 89). 
According to McRuer, it's not possible to speak of "persons with disabilities", once crip theory stands in relation to disability, as queer stands towards homosexuality and transsexuality. That is, a radical critique of institutionalized categories by normativity. Meaning, crip theory deconstructs the boundaries between disabled and non-disabled persons, suggesting that we are all, one way or another, in the same situation, enabling us to break down barriers between "us" and "them"

In Anthropology, we learn that social relationships are built on binary categories, so we propose the use of crip theory as another way of thinking about disability in order to deconstruct the binary logic "disability/ability". This is the perspective guiding this study. Since our interest is not in the Goffmanesque social processes that sociologically create people with disabilities as stigmatized or labeled as "deviant" (Goffman, 1963), but focuses on the debate of disability from one queer perspective. It questions the "normalizing processes marked by the simultaneous production of hegemonic and of subaltern"3 (Miskolci, 2009: 171).

The main objective is to problematize the production of "truths" about disability, departing from crip theory. For this deconstruction, we critically analyzed "Avatar", a science fiction movie, and its representation of the disabled body. What we find interesting in using "Avatar's" approach is that it allows us to make some mention of the analytical and intersectional potential of a crip epistemology of disability. To this cultural discussion, we will link some of its aspects to a perspective autoethnographical in which the authors bring their respective personal narratives as disabled, exercising one cripistemological way to analyze both their bodies as their own dichotomy disability/ability. The expression "autoethnographical" refers to autoethnography, a form of "self-writing" (Foucault, 1992) that combines characteristics of autobiography and ethnography, describing and analyzing (graphy) personal (auto) experience in order to understand the cultural experience (ethno) (Ellis, 2004; Holman Jones, 2005) of people with disabilities. In this sense, having the researcher's body as a simultaneous mediator between the observer and the observed, autoethnography implies the exposition of a vulnerable self (Ellis \& Bochner, 2000), precisely because it is "an autobiographical genre of writing and research that displays multiple layers of consciousness, connecting the personal to the cultural" (Idem, ibidem, p. 739).

The fundamental idea is to show that the social production of disability is also "naturalized" by the dominant knowledge, whose meanings attributed to disability are organized in an apparent binary opposition system to the notions of disability 
and ability, in which the presence of disability supposedly is due the clear lack of ability. Therefore, in a queer/crip analytical disability and ability are revealed as interdependent.

\section{Avatar, the film: an anthropological narrative, queer and crip}

Avatar (2009), a film directed by James Cameron, is a fictional film work permeated by hybrid and mythological narratives. The story is set in the year 2156 on Pandora, one of the moons of Polyphemus planet, in a region covered by lush flora, luminescence, and dense with giant plants that shrink. In Pandora's forest there is also a rich, mythologically exotic and monstrous fauna (Oliveira, 2011), and its local inhabitants, the Na'vi people, blue humanoids about three meters high, having long limbs, a tail, a long braid of black hair ${ }^{4}$, ears and nose resemble a feline whose ways of life inspired a profusion of mythologies and religious influences:

[...] The Na'vi culture condensed resonance of mythologies and various religious influences, ranging from pantheism to tecnopaganism also visiting monotheism, African religiousness and shamanism, and even reincarnationism, to the taste of the beliefs of miscegenation that makes part notably the Latin American universe ${ }^{5}$ (Oliveira, 2011: 4).

In the midst of the paradise of Pandora images, the soldier Jake Sully, a former Marine, is the paralyzed twin brother of the scientist dead shortly before completing the scientific experiment called Avatar. Sully, by having identical genome to his brother, is appointed to replace him. Following the team of scientists, the former soldier gets lost during the expedition and ends up contacting Neytiri, daughter of Eytukan, the head of the Omaticaya clan, and Mo'at, shaman and legitimate representative of Eywa ${ }^{6}$. Neytiri, about to kill him, receives a signal of Eywa, the Great Mother, not to do this. Then Jake is conducted by Neytiri and other Na'vi warriors to her village. After a tense moment, the head of the clan says, "This is the first warrior walker we see. We need to learn more about it". The Omaticaya clan decided then to give a chance to Jake to learn the ways of the Na'vi, to speak the native language and to walk like one. From there, Jake spends three months learning the ways of the Na'vi and goes through all the rites of initiation to become a Na'vi warrior: he learns to ride, hunt, respect and love. In this deep relationship with the tribe, Sully has been accepted by its members as one of them. This cycle is completed a passion for Neytiri. Gradually Jake is delighted with the natives and 
realizes the emptiness of his life as a paraplegic with no prospect in the human "civilized" world and begins to question Western values and himself. Sit torn between two worlds, the loyalty to Colonel Quaritch, to whom he must transmit all the information about the Na'vi, and the loyalty that keeps him increasingly linked to Omaticaya clan. All this was because Jake understood the culture, the native thought the other under a perspectivistic bias:

We must learn that we have a body [the body of your avatar Na'vi], and this learning in the case of Jake Sully will take you to "see" and "feel" of another way, until it is no longer the "driver" and start to think with his own body. Until your mind and your values are converted into a "point of experience", a perspectivism and radical "point of view" amending our own experience of world and the separation between subject and object. In this sense, Avatar can be read as a conversion of instrumental reason and the body/mind dualism to a "thought of the body", in which the body point of view radically changes our identity and subjectivity ${ }^{7}$ (Bentes, 2010: 73).

Avatar is anthropologically inspired by the indigenous populations, with a cosmology in the mold of Amerindian perspectivism proposed by Eduardo Viveiros de Castro (1996), where lifestyles are totally subject to the holistic laws of nature. For example, they produce, collect and hunt without the intention of generating surplus, still have a social organization divided among the warriors, the chief and spiritual leader of the clan. Amerindian perspectivism as a concept emerges in Levi-Straussian-inspired Indigenous Ethnology from "savage thinking” (Lévi-Strauss, 1989) and has another meaning with the "ontological turn" in Anthropology when Viveiros de Castro defines it as a "way of thinking that rejects dualisms typical of Western-modern thought". (Barcelos Neto et al., 2006: 177). Thus, "it is the conception common to many peoples of the continent, according to which the world is inhabited by different kinds of subjects or persons, human and non-human, who apprehend it from different points of view" (Viveiros de Castro, 1996: 115). Hence, in the perspectivist conception, "[...] the classical distinction between Nature and Culture cannot be used to describe dimensions or domains internal to non-Western cosmologies without first passing through a rigorous ethnological critique" ${ }^{10}$ (Viveiros de Castro, 1996, loc. cit.).

Interestingly, parallel to this body/mind dualism, another background permeates Avatar narrative: the duality disability/ability is the thread of the plot, whose 
"essence" is connected to the artificiality of the machines. It is precisely this binary opposition which serves as a starting point to crip theory, leading us to the debate on bodily perfection that McRuer (2006) calls "full physical capacity".

Jake Sully character lives in crisis between two worlds, human and $\mathrm{Na}$ 'vi. As a human, Sully is despised by his abject condition invalid veteran, impure, depraved and disabled; as Na'vi is chosen by his perfection, purity and courage. At first, the human form of Jake, as being raw and disabled, prevails. But it is slowly being replaced by the "pure essence $\mathrm{Na}$ 'vi". Consequently, the victory occurs at the expense of "brutal and defective essence" having as extreme paradigm Colonel Quaritch. In this sense, the Avatar's narrative incorporates the demands of our Western capitalist ableist society by heroes, being able to transcend the bodily limitations and achieve great deeds.

The metaphor of the colonial context between indigenous peoples of the Americas and Oceania and their European invaders is explicit when the narrative of Avatar introduces a former Marine who, like a Na'vi, dreams of flying over dense forests freely, but upon waking as a human faces his harsh reality as a wheelchair user, disabled. As a human, Jake is on Earth in a futuristic and dystopian moment, but a future that has not yet been able to "eradicate" disability even with all the advances of "science". In a passage from the film, Sully says:

They can fix a spinal, if you got the money, but not on vet benefits, not in this economy. A VA check and 12 bucks will get you a cup of coffee. I'm what they call... waitlisted. The Bengal Tiger, extinct for over a century is making a comeback. These cloned tiger cubs at the Beijing Zoo are the latest of a number of species that have been cloned back into existence in the past five years.

We wonder about the interests behind Pandora and its resources and, throughout the movie, we realize that science, militarization and capitalism are mixed in the exploration of the moon and Earth may no longer have enough energy resources. This is a dystopian future that is in the plot of the science fiction Avatar. However, even this plot could tell us about a "cultural shock", recognizable in a colonial fashion to the anthropological gaze - echoing the distinctions nature $\mathrm{x}$ culture, tradition $\mathrm{x}$ modernity, individual $\mathrm{x}$ society and body $\mathrm{x}$ mind - the film portrays a "sci-fi colonial shock", effectively the assault of one species from one galaxy to another. In this way, the Western colonial process also created its "scientific fictions" by assuming that other peoples were inferior to the inhabitants of Earth. To what extent 
does the concept of human take shape? Could not our idea of "original humanity" come from a colonial mix that has been processing the term through science, deadly weapons, and capital?

Avatar's dystopia lies in this imminent end of the human species and the conditions of existence on planet Earth. Jake Sully has the DNA needed to take over the place of his twin brother scientist, but as an invalid ex-military man he has nothing to lose either. "Have nothing to lose", if we comprehend this phrase through a crip reading of the futuristic disabilities projections, according to Kafer (2013), we have two situations of "fictional space-time". The first posits the utopian promise of a world without disabilities, without diseases, without ills and sufferings; The second projects a dystopia, a future environment in which disability and disease have not yet been eradicated and may even become more pronounced due to the very ambiguous nature of technoscience, that is, at the same time that it is the great paradox which has effectively extended human life expectancy, few people access these resources satisfactorily. In the case of the movie Avatar, the dystopia that Sully literally embodies is not only individual and techno-medical, it is economic also, as when Jake comments that genetics can reproduce an extinct tiger, but his spine has not been repaired because he cannot pay for the procedure with his pension as a war veteran. Jake Sully then rejects his body and decides that, like Na'vi, he has nothing to lose by walking back into another body. However, the character Jake Sully is not a symbol of the disabled activist, nor proud of his wheelchair and thin legs. Nor would it be just a disability studies scholar who sees Sully's disability as a social, political and theoretical experience. Sully understands that he has a hole in his life and that his disability is synonymous with a disintegrated body, flawed and marked by absences. Hence, Jake allows himself to be seduced by the Colonel's promise that if he reported the information about Pandora to his military superiors, he would have "his legs back." However, Sully is also seduced by the body of his Na'vi avatar.

This Avatar movie review aims to make a didactic and brief introduction to crip theory, to make a point to the abjection processes of disabled bodies. In this case, the subversive power of the abject body of crip theory is linked to processes of subjection of disability to able-bodied hegemonic patterns because disability is the materiality of abjection in its most radical sense:

Yet there is a strange and really unaccountable silence when the issue of disability is raised (or, more to the point never raised); the silence is stranger, too, since 
so much of left criticism has devoted itself to the issue of the body, of the social construction of sexuality and gender. Alternative bodies people this discourse: gay, lesbian, hermaphrodite [sic], criminal, medical, and so on. But lurking behind these images of transgression and deviance is a much more transgressive and deviant figure: the disabled body (Davis, 1995: 5).

In this sense, the disabled body refers to the idea of crippled as disturbing, degenerated, disposable, morbid, revolting, disgusting, in short, disability is the totalizing synthesis of the aberration of the monster figure (Gil, 1994; Silva, 2000). However, for the crip project, the distinction between disability and ability, registered only in the so disgusting figure of the disabled body, can't be effectively achieved due to the impossibility of achieving the full physical capacity, or "disability is a natural part of life. Everyone will be disabled someday” (Pfeiffer, 1999:106). Furthermore, it is not enough to make positive this universal and virtual projection of disability. As Robert McRuer (2006) points out, not all people who can be considered disabled voluntarily fit in this politically resignified category, especially people who are already considered "not disabled" and who tend to understand, ultimately, that the disabled body is itself the proper example, the great metaphor of the flawed condition of vulnerable, finite and unwanted humanity. Here prefigures the critical and crip conceptualization of a severely disabled position. According to McRuer (2006),

[...] everyone is virtually disabled, both in the sense that able-bodied norms are "intrinsically impossible to embody" fully and in the sense that able-bodied status is always temporary, disability being the one identity category that all people will embody if they live long enough. What we might call a critically disabled position, however, would differ from such a virtually disabled position; it would call attention to the ways in which the disability rights movement and disability studies have resisted the demands of compulsory able-bodiedness and have demanded access to a newly imagined and newly configured public sphere where full participation is not contingent on an able body (McRuer, 2006: 30-31).

This severely disabled position does not seem to get the same weight when we think of abject materiality of the deaf body inhabited by Anahi. To give an example, we illustrate Anahi's remarkable ethnographic experience with a person with Down syndrome, which occurred at Galeão International Airport, Rio de Janeiro, coming from Recife, where she participated from 11 to 13 October 2012 at the invitation of the Ministry of Education (MEC) of Brazil, to the VI Brazilian Congress on Down Syndrome: 
I was sitting waiting for the flight to Florianopolis when suddenly I saw two faces. The first was a face of a person who I had just met at this event, but there was no time for greetings. Soon after, I see the second person's face. An unknown face that instantly disturbed my eyes in time and space, revealing the power of fascination for me: a woman with Down syndrome walked alone and in high heeled shoes, with astonishing ease. She walked by, disappearing from sight in a few seconds. I was staring at the body with Down syndrome walking in high heels, an ability that I do not own, and suddenly I thought about my own prejudice, simply because the owner of the high-heeled shoes is a woman with Down syndrome "independent" and "alone" because she wasn't accompanied. (Anahi's field diary, October 2012).

Thinking of a hierarchy of extraordinary bodies (Garland-Thomson, 1997), I, Anahi, a deaf body, I experienced an extraordinary moment that Rosemarie Garland-Thomson (2009) calls staring, a persistent fascination for the disabled body, feeling the threshold between the sacred and the profane (Douglas, 1966), because at first glance the deaf body is configured in an "ideal body", i.e. a kind of disabled body that approaches the ideas of ordinary bodies. In this unexpected episode, I was the ordinary body; woman with Down syndrome, the extraordinary body:

Extraordinary-looking bodies demand attention. The sight of an unexpected body - that is to say, a body that does not conform to our expectations for an ordinary body - is compelling because it disorders expectations. Such disorder is at once novel and disturbing. This interruption of expectations, of the visual status quo, attracts interest but can also lead to disgust, according to William Ian Miller (1997). Unusual bodies are "unsettling because they are disordering; they undo the complacency that comes with disattendability; they force us to look and notice, or to suffer self-consciousness about looking or not looking. They introduce alarm and anxiety by virtue of their power to horrify and disgust." Such bodies fascinate; they demand that we "sneak a second look" [...] (Garland-Thomson, 2009: 37).

In this sense, although the deaf body provokes fascination through social markers that identify (sign language, the "deaf voice", cochlear implants etc.), it seems to cause less disgust than a Down syndrome body or an amputated or quadriplegic body. Also, my brief stay in Recife, when I closely witnessed desires, flirtations and expressions of public affection among many couples with Down syndrome, this led me to compare the Down syndrome bodies to gay and lesbian bodies when they are not in repressive environments where they feel more comfortable publicly express- 
ing their affections. In fact, beyond the "compulsory heterosexuality" (Rich, 1980), we also have the "compulsory able-bodiedness" (McRuer, 2002).

Marco tells of an experience in which he realized that his "pride" of his "wheelchair body" - half human, half machine - could not be easily understood in certain contexts:

I, as a wheelchair user for 18 years, feel part wheelchair, a cyborg. The symbiosis that I make with her makes me realize the world and reach it with my body-chair. A body that runs, that disassembles, that disengages and engages again in other positions, in other places and contexts. How can I deny that my chair and I are part of each other, thus deny that my being has wheels and engine? A few months ago I got a ride with a friend to a party. Upon arriving at the public parking, we had difficulties opening the car trunk, which only opened from the inside, to withdraw my wheelchair. Maybe our internal movements in the car looked suspicious at that hour of night and some security guards approached us. I was in the car, dismantled in the passenger's seat while listening to my friend arguing with one of them: "I am trying to open the trunk to take out my friend's chair, he is a wheelchair user." ${ }^{11}$ One of the guards immediately shot back: "Wheelchair user?! What is a wheelchair user doing here? This is no place for him!" (Marco's field diary, September 10, 2015).

The "severely disabled" critique of the second author confronts the anxieties that the figure of a disabled person provokes. Why can't they be there? Because of the parking lot is at a Brazilian public university? Because it was at a party? Because the wheelchair testifies the frailty of human beings? The point is that no one wants to take a politically disabled experience as telos of their identity. Yet as much as "[...] if we live long enough, we will all become disabled (Garland-Thomson, 2009: 46)", the wheelchair, as well as crutches, walkers and oxygen atoms pipes are not commonly designated as "dreams of consumption" or totally stripped of its medical and hospital symbology.

This ambiguous figure of the wheel-chair-body - between the healthy and the sick; between life and death; between imprisonment and the freedom of technology; between human and non-human - is the one that brings the idea of "inadequacy" and "transgression". Transgression that creates anxieties, like the figure of cyborg analyzed by Donna Haraway (1987: 5) ${ }^{12}$, because of the breakup with the image of Western ontological distinction between body and machine. In the words of Haraway, 
a cyborg is a cybernetic organism, a hybrid of machine and organism, a creature of social reality as well as a creature of fiction. Social reality is lived social relations, our most important political construction, a world-changing fiction. [...] Contemporary science fiction is full of cyborgs — creatures simultaneously animal and machine, who populate worlds ambiguously natural and crafted. Modern medicine is also full of cyborgs, of couplings between organism and machine, each conceived as coded devices, in an intimacy and with a power that was not generated in the history of sexuality (Haraway, 1987: 1-2).

\section{Disability as stigma and experience queer/crip}

For many people with disabilities, especially those born with a disability or who acquired disability at an early age, disability is often the first queer experience, long before the gender and sexuality ${ }^{13}$. The disabled body is queer. It's a dissident corporeality. The metaphor of "the crippled" shows the proximity of the "monster" of queer theory with the "monster" of crip theory. There is a "crip hierarchy" of queer bodies. Therefore, we must crip queer theory to include subaltern voices of disabled persons, deconstructing the hegemonic assumption that only LGBT bodies are likely to "queering".

In The Body Silent, Robert Murphy (1987) discusses the deviance models of disability in Talcott Parsons and Erving Goffman. According to this author, especially Parsons did not consider what happens when the patient neither does not dies nor gets better, theorizing the fact that people who acquire a disability enter into a permanent liminal state between health and illness. In other words, the discussion of disability is relegated to the background of discussions on rational and deviant models the health and sickness. About the interactionist theory of Goffman, Murphy argues that

Erving Goffman's stigma had great influence on the sociological study of disability by providing a common framework within which the handicapped, criminals, and certain minority groups could be seen as sharing a common lot: They are all outsiders, deviants from social norms. There are, however, problems with this framework. First of all, it throws into one pot people who are deliberate violators of legal or moral standards and persons who are in no way to blame for their stigmatized state. A person chooses to follow a life of crime, but nobody asks to be born a black, and certainly nobody wants to become a quadriplegic. These stations in life are visited upon people by inheritance or bad luck, not through choice. This, of course, does not prevent others from blaming the victim, and all too 
many benighted whites look on blacks as lazy and unintelligent people who prefer welfare and crime to working for a living. Even the disabled are often vaguely blamed for their condition, or at least for not achieving maximum recovery. And as sure proof that they bear stigmatized identities, physical impairment is looked upon as something that does not happen to respectable people. The blind are folks who make brooms in sheltered workshops, or who sit on street corners with cups. They certainly do not belong among the upwardly mobile (Murphy, 1987: 129).

In fact, the concept of stigma strongly influenced sociological studies on disability by providing a framework in which "disabled", "criminals" and other minority groups would present "common destiny": all are outsiders and deviant social norms. However, to Murphy (1987), this frame also presents problems by putting together and classifying as "stigmatized" people who deliberately violate legal or moral norms with those who have no blame for their condition. A person can choose to follow a life of crime, but no one asks to be born black, much less choose to become quadriplegic. These are events that occur through inheritance or "bad luck". If to be disabled is less of a "choice" and more about "bad luck", or vice versa, it expands the scope of the stigma concept, to exchange their conventional content by another sense of its meaning, especially in the context of "politics of appearance" as proposed by Rosemarie Garland-Thomson (2009) to refer to the "abominations of the body" described by Goffman as "stigmata hierarchy" that begins with disabilities:

[...] Human variation, in other words, is seldom neutral. "Abominations of the body" are in the eye of the well-acculturated beholder. Modern culture's erasure of mortality and its harbinger, bodily vulnerability, make disabled bodies seem extraordinary rather than ordinary, abnormal instead of mundane - even though in fact the changes in our function and form that we think of as disabilities are the common effects of living and are fundamental to the human condition. What Goffman describes as "abominations" come to most ordinary lives eventually. If we live long enough, we will all become disabled (Garland-Thomson, 2009: 44-46).

Here there is a relationship between Goffman's concept of stigma (stigmatized bodies) and the idea of abjection (abject bodies) of queer theory. The hierarchy of corporealities, including the "abominations of the body" and all the contrasts between ordinary and extraordinary bodies (Garland-Thomson, 1997), organizes the able-bodiedness of our social structure little sensitive to body diversity.

For queer thought, all "difference than [if] want to be assimilated or tolerated, 
and therefore its form of action is much more transgressive and disturbing"14 (Louro, 2001: 546), may also be considered queer. From this perspective, disabled bodies are also queer. The "invention of disability" also produces an "exclusionary matrix" that "requires the simultaneous production of a domain of abject beings" (Butler, 1993: 3). By abject we understand the subjects whose bodies do not fit the prevailing social standards. For Butler (1990), the "abnormal" is seen as the "constitutive outside" of the subject "normal" and just designates the "uninhabitable" areas of social life. These zones of abjection are densely populated by those who do not enjoy of a subject hierarchy, there is a need to constitute a "foreign" composed of "not subject" in order to prove as less human for such a matrix can remain hegemonic.

However, as with the queer/crip bodies of the "global south", disability also needs "to be understood in the context of the violence of colonization and neocolonial power" (Connell, 2011: 1369). From this "southern perspective," we should think of Jake Sully as a "settler of the north" seduced by the "colonized from the south". How to access "southern bodies" if Sully is from the "north" and, above all, by his position of geopolitically localized subject, let himself be seduced by the other when he assumed the body of his Na'vi avatar. How do the bodies of the authors of this paper enter the "moral economy" of southern bodies to think of the "global north"? Are we necessarily from the south because we are Brazilian or are in Brazil? For Viveiros de Castro (2002), the other can be understood as possibility of relating to something beyond the self. In this sense, the other is the structure in which the self imagines the existence of other. For this reason, we recognize our position as "southern bodies" in constant tension between being in the "global south" and being in the "Brazilian academic north": in the first case we are post colonized Brazilians, in analogy to the metaphor of being Na'vi in a context of global binary division of the world; in the second case we are in good federal universities of the "center" (represented by the states that compose the southeastern, south and central-west regions of Brazil), enjoying relative academic autonomy and material resources for the research and production of knowledge about disability, so that we are often interpreted by the "academic periphery" (represented by the states that make up the northern and northeastern regions of the country) as "settlers" of certain social thoughts about disability.

In the next section, we will focus on "cripness" of our autobiographical narratives that permeate the crip politicization of our disabled body to Avatar fiction: Marco as a body attached to a wheelchair and being carrier of a genetic disease; and Anahi's 
deaf body connected to a cochlear implant. In the perspective of prosthetic narrative, the connection of Avatar with our disabled bodies is supported by the notion of the hybrid. The hybridization of Sully human and Sully Na'vi helps us to speak of our hybrid condition physically-disabled-wheelchair-body and deaf-cochlear-implanted-body respectively.

\section{My body, my wheelchair}

The fact that I'm a motorized-wheelchair-body, goes beyond the fact that I was a "user of a motorized wheelchair" or a "person on a wheelchair". The first memory I have about wheelchair comes with my refusal and fear, as a child, to not become 'it's' "prisoner". I grew up hearing that one of the effects of "my genetic condition" would be the progressive loss of all muscle tone. One of the major medical concerns, that served as a rehabilitative motto for my incurable clinical prognostics, was to keep my degenerating body as "active and independent" as possible. Be "active and independent" meant keeping up my ability to walk, and my standing position, with a lot of physiotherapy and psychology.

Amid these discourses, the inevitable feeling of weakness consumed me all the more: I could no longer hold my eight-year-old body standing for long; my arms were trying in vain to sustain me under the crutches that had, up until that time, accompanied me. With every failed, flawed step, every time I lost muscle control in my legs, leading to an inevitable fall to the ground, it became less painful to see myself as a "wheelchair bound". I tried hard not to use 'it'. I saw the wheelchair as a "prison" that would not allow me to do anything; but, at the same time, I did not see with the same "critical concern" the heavy iron structure that embraced my legs and hip and that was the last "prosthetic therapy" to save my bipedalism (seen as an index of greater independence).

As my muscle degeneration is inevitable, as well as the loss of my ability to walk, the heavy paraphernalia that helped me to keep standing up. The "dreaded" wheelchair was the only way for me to continue playing around and going to school. Gradually the process by which I stopped seeing "it" involves me in a simultaneous metaphorical and literal process as I felt that "she" embraced me with "her" arms and metal supports and foam, which held me up and off the ground. I perceived it as another way to move around, to communicate with others. To find a way of living "stuck" in an apparatus seen as culturally malevolent, allowed me, over time, to create a symbiosis with this machine. 
My wheelchair is not exactly a possession, it, she became the fundamental means of my own condition of social existence, including as a "disabled person". As she, it and I we were inappropriate for many spaces; she and I were, and are, a cybernetic hybrid configuration, as Haraway (1987) defines cyborgs. There is no presence of one without the other. The apparent simple act of dismounting "my" wheelchair starts at the exact moment that we are tortuously uncoupled for it to be folded, defragmented in parts to fit in a car's trunk. This disassemblage consumes me in the anxiety of our distance. I feel inert to be outside of her and I wonder what my "real" legs are paired with the momentary stillness of the chair's wheels. In this mixture of flesh, bone, metal, plastic, and electricity, I feel a motorized-wheelchair-body, a rolling-body, a mechanical organism disfigured of its supposed essences.

What makes me disabled? The wheelchair? The perception of others about my body? My degenerative disease that leaves me "cock high in the world" (Mairs, 2001: 54). The world that does not include bodies extremely out of social, cultural, and biological norms and expectations? What comes first? Donna Haraway's cyborg refers to a noise in the cultural and scientific certainties of human ontology, and allows us to think as ambiguous beings, indeterminate or multiple sources. To prefer the idea of being a cyborg instead of a goddess (Haraway, 1987; Meekosha, 1999; Puar, 2012) the author tenses a critical idea of embodied consciousness by devices and power techniques historically locatable. The possibility of (un)learning the body emerges not only as a means of meeting a pre-existing world, but also to create new bodies-worlds contingent to each other.

\section{My cochlear implant, my crip sex toy}

My deaf body, my cochlear implant. My cochlear implant, my crip sex toy. My crip sex toy, my subjectivity. I do not have the primacy of "deaf knowledge" because I do not intend to be recognized first as deaf. Deafness is part of my identifications, but it is not something with which I have a main identification. However, if my deafness is the "stigma" in evidence, people tend to take it as my "primary identity". This intrinsic characteristic of my body obscured my other political subjectivities: being a woman and lesbian. The ableist and hetero-cis-normative social structure generally tends to contribute to this disappearance, to the extent that society only sees me as deaf. Deafness is my first queer experience, but it was the consciencia mestiza (Anzaldúa, 1987), not "Deaf consciousness", that allowed me to go beyond the deafness so I can move "constantly out of crystallized formations" (Anzaldúa, 2005: 706). 
My deaf body is mediated by a machine, the so-called cochlear implant, a highly sophisticated technology to enhance hearing ability in a more effective way than an ordinary hearing aid. In a human-machine interface, in the terms of Haraway (1987), the cochlear implant deaf-hybridization could be thought of as a counter power to the "Deaf Pride", with the motto inscribed "Bionic Ear Pride". Considering cybernetics as "the art of ensuring the effectiveness of an action" (Couffignal, 1968: 23), I propose to think the cochlear implant-deaf relationship under these cyber effects when the cochlear implant as a "foreign agent" ensures the deaf body's effectiveness of mechanical ability to listen. Here the cyborgization process is configured in construction be deaf in connection with a cochlear implant, performing social measures, since both are involved in the same ratios.

In 1998 I had the first contact with the theoretical assumptions of the Deaf Studies from reading academic texts in Portuguese on "Deaf identities". In my view, these texts are filled with "accusatory categories", the sorting of deaf people into various categories of deaf identities being counterproductive because it split us into "good deaf" and "bad deaf". Good deaf would the Deaf with letter "d" uppercase, those who communicate and have sign language as their first language, being fans of "Pride Deaf". The "bad deaf" would be the "oral deaf" and users of the Portuguese language as a first language in Brazil, those who speak, do lip-reading and use "hearing technologies".

The talking, lip reading and "hearing technologies" of cochlear implants are considered by the "good deaf" as "things of hearing people" and therefore should be rejected. Although I don't subscribe to these ideas "in these terms", it is true that the hearing-deaf relationship does not cease to be a relationship majority-minority, where inequality is also evident through communication and the ability to hear. In this sense, just as the "white privilege" or racism against blacks and the "male privilege" or sexism against women can be, respectively, systems of oppression based on race/ethnicity and gender, the "hearing privilege" or audism against deaf people can be understood as a system of oppression based on hearing ability (Eckert \& Rowley, 2013; Ha'am, 2017). However, regarding the cochlear implant, as cybernetic prosthesis it is treated by many Brazilians Deaf with some disgust, a "bad thing", almost automatically a "negative experience" to be avoided, often without considering subjective aspects involved in each particular situation and that demand in a continuous exercise of relativity.

If sexuality in human life is a subjective meaning variable in different cultures, so 
I can say the subjectivity of cochlear implant-deaf experience. One of the powerful dimensions of the cyborg and queer/crip experience with cochlear implants are the sounds of sex we produce and heard during the sexual relations. There are reports of physical disabled people that show how some erotic-sexual nuances and seduction mechanisms are designed from their wheelchairs, sometimes in a sensual dance or as extension of their disabled bodies in sexual and/or erotic games practices (Oliveira, 2016). But reports of the sexual practices of deaf people are scarce, especially when they involve the use of cochlear implants. This difficulty is due to the fact that deafness be, at first sight, an "invisible disability", i.e. the "surface" the deaf body does not present "deformed" to be considered worthy of reflexivity in the field of the dissident sexualities. There is a gradation of disability, or "crip hierarchies" of disabled bodies, with the deaf body very close to the first level of the hierarchy.

In fact, for many cochlear implant users this technology has become an ingredient to more sexual satisfaction. They like to make love with cochlear implant, because they love to hear the sounds of sex. Thus, listening may come to represent a very particular positive dimension of subjective experience of deaf people with cochlear implants. In my case, it is not different. Making love with cochlear implant affects my libido, greatly changing the sexual scripts, once I stop to discover and actively participate in the sounds present in seduction games in bed. So my cochlear implant is a fetish, affectionately treated as sex toy. My cochlear implant, my crip sex toy. This is one of the reasons why those Deaf who have never experienced a cochlear implant can't and should not refer to it as a "bad thing". Sex with cochlear implant is also a powerful experience because of the subjectivity of each subject. However, as in any experience of the subject, the subjectification of the cochlear implant should not do without the subjective position of the subject, i.e. the experience with a cochlear implant is tributary of the subjective position of the deaf person.

\section{Final considerations}

Sully has dreams in which their freedom is to fly over heavy trees canopies. Dream of freedom in his narrative are contrasted by his image among the people of a planet Earth with no future. Sully does not see his disabled body as a creative power. The former paraplegic Marine believes that in his life there is a hole and what it lacks is in his life before the accident. This fetish returns to a previous alleged bodily life, in a way, is the same fetish encouraged by rehabilitative historic speech that Henri-Jacques Stiker (1999: 122) comments hold its reference to a "[...] 
assumed prior, the normal state." Stiker continues to state that

this iterative term to designate the rehabilitation initiative, especially from the 1920s onward, is remarkable in its own right. It is applied to congenital cases as well as the adventitious. It implies returning to a point, to a prior situation, the situation that existed for the able, but one only postulated for the others (Stiker, 1999, loc. cit.).

It is this will to walk again that animates Jake Sully for much of the film narrative and his plotting against the Na'vi. It is for this same freedom that walking again is symbolic and seduces Sully to use as avatar the powerful Na'vi body created "in vitro". A disabled, paraplegic, Jake Sully works as the foundation of other forms of knowledge and access to inhuman information at the same time he needs to be both dismissive and overprotected. This is precisely one of the points that makes us think in an analytical queer/crip of disability.

We all know that Jake Sully, when using the Na'vi body remains with his human body in a broadcasting room. If his human body suffers any damage, the experience of using the body as Na'vi Avatar fails. However, only we realize such fragility of the human body condition when in a deadly struggle, while immersed in Avatar, the cabin in which lies the body of Sully is broken. The former soldier is vulnerable to the toxic gas moon Pandora and its Avatar goes off when the human lungs can't breathe. One of the most beautiful scenes of the film, we see the warrior Neytiri, with its slender, blue-bulk, holding in her lap, in comparison, the small body of her beloved, almost dead. This is where we have our "able-bodied epiphany" when the end of the movie to recognize that Jake Sully survived and become the Omaticaya clan hero, his dying body to be left out, "discarded".

The crip theory critique to the notion of a "complete physical capability" seems to cross an analysis of normalization that results, for instance, from the misunderstanding of what constitutes a queer analysis about the relation between homophobia and compulsory heterosexuality. One might see that as a result from the fact that the problematizing towards physically able bodies did not strongly benefit from the intersection among categories such as sexuality, race, ethnicity, and disability - in the sense of a "sexualization/racialization of disability" or a "disabling of sexuality and race" whereas queer theory itself relies on an intersectional approach to discuss the sexualization of race and the racialization of sexuality. 
Crip theory questions the normalization of bodies. It questions the exclusion of ableism as intersectional discrimination matrix in the feminist and queer theories. It questions the "compulsory able-bodiedness" because it is socially and culturally marked by a "hierarchy of corporealities" in which to "dwell in the world" (Butler, 1990) certain bodies seem to be "more acceptable", "selected" or "privileged" that others. By questioning a hierarchy of bodies, the crip theory necessarily covers the size of non-hegemonic sexualities. Thus, queer theorists must or should know about crip theory, since queer theory relates to a "crip hierarchy" of queer bodies.

We also have a doubly tensioned, divided experience: we are seen by the "northerners" as the "global south", the "third world," "subalternized localities in global political economy," and it seems that in many ways we have to recognize ourselves in these terms. At the same time, we are often seen by other compatriots as the "academic north"15: "very theoretical," "with research resources," and "with full academically activism conditions." Paradoxically, it is precisely because of this our hybrid condition that we are generalized as from the south (global) and from the north (national) that our critical power resides to produce a southern crip thinking.

Recebido: 14/02/2019

Aprovado: 09/04/2019

Acknowledgments The authors express their thanks to Pamela Block for reviewing the manuscript's English. Anahi expresses her thanks to Capes for granting her doctoral scholarship, and to $\mathrm{CNPq}$ for funding of the project Feminist Theory, Queer Theory or Contemporary Social Theories?: the field of Gender Studies and Sexuality in Brazil (Process No. 402545/2010-9). Marco wants to say thanks to the CAPES and $\mathrm{CNPq}$ for his doctoral fundings.

Anahi Guedes de Mello is PhD in Social Anthropology from Federal University of Santa Catarina (UFSC), in Florianópolis, Brazil. Researcher of the Núcleo de Identidades de Gênero e Subjetividades (NIGS), at the UFSC's Department 
of Anthropology, and of the Núcleo de Estudos sobre Deficiência (NED), at the UFSC's Department of Psychology. She is also an associate researcher at Anis Instituto de Bioética, in Brasília, Brazil. ORCID: 0000-0002-5536-7171. Contact: anahigm75@gmail.com

Marco Antonio Gavério is a PhD student at the Pos-Graduate Program in Sociology, at the Federal University of São Carlos (UFSCar), in São Carlos, Brazil. Researcher of the group Sexualidade, Entretenimento e Corpo (SEXent), at the UFSCar's Department of Sociology. ORCID: 0000-0002-0744-3520. Contact: marcaosemacento@gmail.com

\section{Notas}

1. This term lies critically on to the obligation of women to undergo a heterosexual relationship and maternity.

2. Going further, crip theory aligns with the premises of symmetrical anthropology, since the symmetrical thinking point of departures the construction of a conceptual apparatus that reconfigures anthropology and for it uses concepts that overcome dualistic renderings of the world, such as network, symmetry, multinaturalism, relationship.

3. Free translation.

4. This long braid works as "nerve terminal" for communication, transmission and sharing of feelings, practices and traditional knowledge among the $\mathrm{Na}$ 'vi and their ancestors, the animals, plants, in short, everything that exists in Pandora.

5. Free translation.

6. The Na'vi preserve their beliefs, customs and traditions and are religiously attached to their land, considered the abode of their goddess Eywa. In this sense, in Pandora everything and everyone is connected to Eywa, through a network of energy that connects all living beings.

7. Free translation.

8. Free translation.

9. Free translation.

10. For a good introductory text on perspectivism, see Bruno Latour (2009).

11. Note: in Brazilian Portuguese language, "cadeirante" does not have the same sense of "wheelchair user" in English. "Cadeirante" is a native category widely used in Brazil. "Wheelchair user" may be translated in Portuguese as "usuário de cadeira de rodas" as if the chair were separated from the person. Already "cadeirante" is the embodiment of the chair to the person. Thus, the term "cadeirante" combines and transforms the chair and the person into a single thing, as a cyborg. In this sense, the chair is a person because it's an extension of the user's body.

12. Regarding other ruptures mentioned by Haraway that erupt through the cyborg are: the breaking of the modern western boundaries between 'human and animals' and within the limits of the 
'physical and non-physical'. For a feminist-queer-crip analysis of this work of Haraway and some of its developments in Disability Studies, see Kafer (2013:103-128)

13. See too Eli Clare (2001, p. 361): "Let me begin with my body, my disabled queer body. I use the word queer in both of its meanings: in its general sense, as odd, quirky, not belonging; and in its specific sense, as referring to lesbian, gay, bisexual, and transgender identity. In my life, these two meanings have often merged into one. Queer is not a taunt to me, but an apt descriptive word. My first experience of queerness centered not on sexuality or gender, but on disability. Early on, I understood my body to be irrevocably different from those of my neighbors, playmates, siblings. Shaky: off-balance; speech hard to understand; a body that moved slow, wrists cocked at odd angles, muscles knotted with tremors. [...] Only later came gender and sexuality. Again I found my body to be irrevocably different."

14. Free translation

15. And here the inversion of the north-south poles occurs in the regional geopolitics of Brazil, where the "southern states", represented by the south, are more economically and politically "evolved" than the "northern states," represented by the northern and northeastern regions

\section{References}

ANZALDÚA, Gloria. 1987. Borderlands/La Frontera: the new mestiza. San Francisco: Aunt Lute Books Press.

ANZALDÚA, Gloria. 2005. "La consciencia de la mestiza/Rumo a uma nova consciência”. Revista Estudos Feministas, v. 13, n. 3, p. 704-719.

CAMERON, James. 2009. Avatar. Los Angeles, CA: Twentieth Century-Fox, 2010, DVD.

BARCELOS NETO, Aristóteles; RAMOS, Danilo; BÜHLER, Maíra Santi; SZTUTMAN, Renato; MARRAS, Stelio; MACEDO, Valéria. 2006. “Abaeté, rede de antropologia simétrica: entrevista com Marcio Goldman e Eduardo Viveiros de Castro”. Cadernos de Campo, 15, n. 14-15, p. 177-190.

BENTES, Ivana. 2010, "Eu vejo você: antropologia reversa em Avatar, ciber-índios, pós-cinema ou como arrancar um pensamento complexo dos clichês”. In: FELINTO, Erick; BENTES, Ivana (eds.). Avatar: o futuro do cinema e a ecologia das imagens digitais. Porto Alegre: Sulina. p. 55-119.

BUTLER, Judith. 1990. Gender trouble: feminism and the subversion of identity. New York: Routledge. BUTLER, Judith. 1993. Bodies that matter: on the discursive limits of "sex". New York: Routledge.

BUTLER, Judith. 2004. Undoing gender. New York: Routledge.

CLARE, Eli. 2001. "Stolen bodies, reclaimed bodies: disability and queerness”. Public Culture, v. 3, n. 3, p. 359-365.

CONNELL, Raewyn. 2011. "Southern bodies and disability: re-thinking concepts". Third World Quarterly, v. 32, n. 8, p. 1369-1381.

COUFFIGNAL, Louis. 1968. La Cybernétique. 3. ed. Paris: Presses Universitaires de France.

DAVIS, Lennard J. 1995. Enforcing normalcy: disability, deafness, and the body. London; New York: Verso.

DERRIDA, Jacques. 1998. Of Grammatology. Translated by Gayatri Chakravorty Spivak. Baltimore: 
John Hopkins University Press.

DOUGLAS, Mary. 1966. Purity and Danger: an analysis of the concepts of pollution and taboo. London: Routledge.

ECKERT, Richard C.; ROWLEY, Amy J. 2013. "Audism:A theory and practice of audiocentric privilege”. Humanity \& Society, v. 37, n. 2, p. 101-130.

ELLIS, Carolyn. 2004. The ethnographic I: a methodological novel about autoethnography. Walnut Creek, CA: AltaMira Press.

ELLIS, Carolyn; BOCHNER, Arthur P. 2000. Autoethnography, Personal Narrative, Reflexivity: researcher as subject. In.: DENZIN, Norman K.; LINCOLN, Yvonna S. (Eds.). 2. ed. Handbook of qualitative research. Thousand Oaks: Sage Publications.

FOUCAULT, Michel. 1990. The history of sexuality.V. 1: an introduction. New York: Vintage Books.

FOUCAULT, Michel. 1992. A escrita de si. In.: FOUCAULT, Michel. O que é um autor? Lisboa: Passagens.

GARLAND-THOMSON, Rosemarie. 1997. Extraordinary bodies: figuring physical disability in American culture and literature. New York: Columbia University Press.

GARLAND-THOMSON, Rosemarie. 2009. Staring: how we look. New York: Oxford University Press.

GIL, José. 1994. Monstros. Lisboa: Quetzal Editores.

GOFFMAN, Erving. 1963. Stigma: notes on the management of spoiled identity. New York: Simon and Schuster.

HA'AM, Boaz A. 2017. "Deafness as disability: countering aspects of the medical view". Public Reason, v. 9, n. 1-2, p. 79-98.

HARAWAY, Donna Jeanne. 1987. "A manifesto for cyborgs: science, technology, and socialist feminism in the 1980". Australian Feminist Studies, v. 2, n. 4, p. 1-42.

HOLMAN JONES, Stacy. 2005. Autoethnography: making the personal political. In.: DENZIN, Norman K.; LINCOLN, Yvonna S. (eds.). 3rd ed. Handbook of qualitative research. Thousand Oaks: Sage Publications.

KAFER, Alison. 2013. Feminist, Queer, Crip. Bloomington: Indiana University Press.

LATOUR, Bruno. 2009. “Perspectivism: 'type' or 'bomb”?". Anthropology Today, v. 25, n. 2, p. 25.

LÉVI-STRAUSS, Claude. 1989. O pensamento selvagem. Campinas: Papirus.

LOURO, Guacira Lopes. 2001. "Teoria Queer: uma política pós-identitária para a Educação”. Revista Estudos Feministas, v. 9, n. 2, p. 541-553.

MAIRS, Nancy. 2001. Waist-high in the world: a life among the nondisabled. Boston: Beacon Press.

MCRUER, Robert. 2002. "Compulsory able-bodiedness and queer/disabled existence". In: SNYDER, Sharon L.; BRUEGGEMANN, BRENDA J.; GARLAND-THOMSON, Rosemarie (Eds.), Disability studies: enabling the humanities. New York: Modern Language Association of America.

MCRUER, Robert. 2006. Crip Theory: cultural signs of queerness and disability. New York: New York University Press.

MEEKOSHA, Helen. 1999. "Superchicks, clones, cyborgs, and cripples: cinema and messages of bodily trans- 
formations”. Social Alternatives, v. 18, n. 1, p. 24-28.

MISKOLCI, Richard. 2009. "A teoria Queer e a sociologia: o desafio de uma analítica da normalização”. Sociologias, n. 21, p. 150-182.

MURPHY, Robert F. 1987. The body silent: the different world of the disabled. New York: Henry Holt and Company.

OlIVEIRA, Adriano Messias de. 2011. "De Avatar à Centaura Mexicana: o monstro e o monstruoso na produção de sentidos da América quinhentista”. Paper presented at the $1^{\circ}$ Congresso Mundial de Comunicação Íbero-Americana, São Paulo, SP. p. 1-6.

OLIVEIRA, Everton Luiz de. 2016. "Pô, tô vivo véio!": história de vida e sexualidade de pessoas com deficiências físicas. Tese [Doutorado em Educação Física]. São Carlos: Universidade Federal de São Carlos.

PFEIFFER, David. 1999. "The categorization and control of people with disabilities". Disability and Rehabilitation, v. 21, n. 3, p. 106-107.

PUAR, Jasbir K. 2012. “I would rather be a cyborg than a goddess”: becoming-intersectional in assemblage theory”. PhiloSOPHIA: A Journal of Continental Feminism, v. 2, n. 1, p. 49-66.

RICH, Adrienne. 1980. "Compulsory heterosexuality and lesbian existence”. Signs: Journal of Women in Culture and Society, v. 5, n. 4, p. 631-660.

SILVA, Tomaz Tadeu (org.). 2000. Pedagogia dos Monstros - os prazeres e os perigos da confusão de fronteiras. Belo Horizonte: Autêntica.

STIKER, Henri-Jacques. 1999. A history of disability. Ann Arbor: University of Michigan Press.

VIVEIROS DE CASTRO, Eduardo. 1996. “Os pronomes cosmológicos e o perspectivismo ameríndio”. Mana, v. 2, n. 2, p. 114-144.

VIVEIROS DE CASTRO, Eduardo. 2002. “O nativo relativo”. Mana, v. 8, n. 1, p. 113-148. 
Facts of cripness to the Brazilian: dialogues with Avatar, the film

Abstract: The influence of queer theory on the humanities is also reflected in disability studies, contributing to the emergence of crip theory. While the main axiom of queer theory postulates that contemporary society is governed by hetero-cis-normativity, crip theory is supported by the socially constructed postulate of compulsory able-bodiedness that is not very sensitive to the body's diversity. The translation of the term crip into the category of crippled in Portuguese (i.e. aleijado) is a way of giving the same sense of the word in English, indicating an area reserved for people with disabilities. Considering that gay and lesbian studies initially focused their investigations on the question of homosexuality being a "natural" or "unnatural" behavior, remaining within a binary logic, queer theory expands the investigative focus by encompassing any kind of sexual practice or identity that circumscribes normative or deviant categories. From this perspective, disabled bodies are also queer. The objective of this work is to discuss the analytical and intersectional potential of a queer/crip epistemology in the constitution of disability experience from the "global south", based on autoethnographic accounts and analysis of the Avatar movie.

Key Words: disability, crip theory, queer theory,epistemologies of the south.
Fatos da aleijadice à brasileira: diálogos com Avatar, o filme

Resumo: A influência da teoria queer nas humanidades também se refletiu nos estudos sobre deficiência, contribuindo para a emergência da teoria crip. A teoria queer postula que a sociedade contemporânea é regida pela hetero-cis-normatividade, enquanto na teoria crip a crítica está no postulado da corponormatividade de nossa estrutura social pouco sensível à diversidade corporal. A tradução do termo crip para aleijado em português é uma forma de dar o mesmo sentido da palavra em inglês, desvelando a zona de abjeção reservada às pessoas com deficiência. Considerando que os estudos gays e lésbicos inicialmente focaram suas investigações na questão da homossexualidade ser um comportamento "natural" ou "antinatural", permanecendo dentro de uma lógica binária, a teoria queer expande o foco investigativo ao abarcar qualquer tipo de prática sexual ou identidade que estejam na fronteira de categorias normativas ou desviantes. Desde essa perspectiva, os corpos deficientes também são queer. O objetivo deste trabalho é discutir, a partir de relatos autoetnográficos e da análise do filme Avatar, o potencial analítico e intersecional de uma epistemologia queer/crip na constituição da experiência da deficiência desde o "sul global".

Palavras-chave: deficiência, teoria crip, teoria queer, epistemologias do sul. 